\title{
Design of Vertical Pressure Vessel Using ASME Codes
}

\author{
Najeeb A. Yahya ${ }^{1 *}$, Othman M. Daas ${ }^{2}$, Nureddin O. Fahel Alboum ${ }^{3}$, Ahmed H. Khalile \\ Department of Mechanical \& Industrial, College of Engineering, Zawia University, Libya \\ DOI: https://doi.org/10.21467/proceedings.4.33 \\ * Corresponding author email: nyahya@zu.edu.ly
}

\begin{abstract}
While preparing this paper many of companies are subjecting to the hazards resulted from the incorrect design and manufacturing of pressure vessels (leakage or Explosion), those used in the storage of dangerous liquids or pressurized fluids. The main objective of using the pressure vessels are used as containers to contain many of materials such as: liquids, air, gases, chemical compounds and fuel, moreover pressure vessels considered as important prop in petroleum and chemical industries especially as storages for oil and chemical components. The main goal of this paper to shed light on the importance processes of the Mechanical Design and Analysis of Vertical Pressure Vessels, also to give scratch to prevent this hazard using. The used model is very close shape to the used vessels in such companies. The design of vertical pressure vessel is carried out using the American Society of Mechanical Engineers (ASME) Codes. ASME section VIII and Division 1 are normally used in design. Various components of the pressure vessel are designed by calculating the appropriate design factors like thickness of the shell, head, stress analysis etc. to validate the design result the pressure vessel is modelled and analyses in Solid works software. The engineering geometrical drawings and Finite Element Analysis (FEA) have been achieved on the targeted model of Vertical Pressure Vessel by using very moderate computer programs to give results agreed and compatible with correct choose of ASME codes. Throughout this paper, the permissible pressures are very considered as well as determination the wall thickness of the vessel is firmed to reach the acceptable maximum stresses. Furthermore, the design of targeted pressure vessel has been achieved under the range of ASME codes and engineering standards to reach the allowable designing boundaries.
\end{abstract}

Keywords: Pressure vessels; ASME codes; Standards; Maximum stresses; Solid works software.

\section{Introduction}

Pressure vessels are one of the main equipment those widely used in industrial facilities. The pressure vessels defined as cylindrical or spherical vessels those designed to store or hold pressurized liquids, gases or fluids with a differential pressure between inside and outside.

Usually, the inner pressure is higher than the external pressure, except in some cases. The fluid inside these vessels may undergo a change in state as in the case of steam boiler or may

(C) 2018 Copyright held by the author(s). Published by AIJR Publisher in Proceedings of First Conference for Engineering

Sciences and Technology (CEST-2018), September 25-27, 2018, vol. 2 .
This is an open access article under Creative Commons Attribution-NonCommercial 4.0 International (CC BY-NC 4.0) license, which permits any non-commercial use, distribution, adaptation, and reproduction in any medium, as long as the original work is properly cited. ISBN: 978-81-936820-6-7 
combine with other reagent as in the case of chemical reactor. The reservoirs designed such that no leakage can occur, also deal with operational levels of high pressure and high temperatures[1]. The pressure vessels are differ in terms of capacity, heat and pressure, some of these vessels may contain more the half million barrels of crude oil, the temperatures sometimes more than $200{ }^{\circ} \mathrm{C}$ specially in asphalt tanks and high viscosity products, the temperatures may slope down to $14^{\circ} \mathrm{C}$ especially in tanks store hydrocarbons materials such as propane, butane and others, so it is necessary to understand the types of reservoirs and their components as well as the appropriate storage methods[2]. Pressure vessels usually are cylindrical or spherical with semi-spherical covers (domes) and cylindrical tanks. Cylindrical vessels very wide in use and very simple to manufacture and ease in use such as boilers, heat exchangers, refineries ...etc. According to the importance of pressure vessels, many of published researches achieved especially in Designing and Analysis of Stresses on the reservoirs as well as the exact use of designing standards, methods of numerical analysis and the mathematical simulation models to identify different collapse occur on reservoirs.

(Apurva R) [3] and friends have used ASME codes to design and analysis of pressure vessel by using maximum permissible pressure to find the factor of safety to obtain the finest design, furthermore, the Finite method element used to study the stresses distribution those deal to reservoir failure. (B. Thakkar and S. Thakka) [4] are designed and constructed in accordance with ASME codes Section VIII, Division 1 by changing internal pressure values of the vessel to obtain the premium design and determination of critical points of collapse in vessel's body. (V. Kumar)[5] used the ANSYS program to design and analyze the loads on the installation fits of horizontal pressure vessel to determine the high stresses concentration between the stiffeners and the wall of the tank, the results were compared with permissible strain of design. (Maharishi J. Bhatt) [6] Studied the design of connecting the nozzle with the tank wall, also to connect this nozzle with upper or lower cover according to ASME codes Section VIII, Division 1. Generally speaking, this paper includes the steps designing calculations to support the nozzle with the tank body and connecting regions.

\section{History of ASME Codes for Pressure Vessel}

Pressure vessels store energy and as such, have inherent safety risks. Many states began to enact rule and regulations regarding the construction of steam boilers and pressure vessels following several catastrophic accidents that occurred at the turn of the twentieth century that resulted in large Loss of life. By 1911 it was apparent to manufacturers and users of boilers and pressure vessels that the lack of uniformity in these regulations between states made it difficult to construct vessels for Interstate commerce. A group of these interested parties appealed to the Council of the American Society of Mechanical Engineers to assist in the formulation of standard specifications for steam boilers and pressure vessels. (The American Society of Mechanical Engineers was organized in 1880. As an educational and technical society of mechanical engineers.) After years of development and Public comment, the first

Proceedings of First Conference for Engineering Sciences and Technology (CEST-2018), vol. 2 
Design of Vertical Pressure Vessel Using ASME Codes

edition of the Code, ASME Rules of Construction of Stationary Boilers and for Allowable Working Pressures, was published in 1914 and formally adopted in the Spring of 1915. The first Code rules for pressure vessels, entitled Rules for the Construction of Unfired Pressure Vessels, followed in 1925. From this simple beginning the Code has now evolved into the present eleven Section document, with multiple subdivisions, parts, subsections, and Mandatory and non-mandatory appendices.

Almost all pressure vessels used in the process industry in the United States are designed and constructed in accordance with Section VIII, Division 1. A pressure vessel is a closed container designed to hold gases or Liquids at a pressure different from the ambient pressure. The end caps fitted to the cylindrical body is called heads. Pressure vessels are used in a variety of applications. These include the industry and the private sector. Steel pressure vessel in the industrial sector, pressure vessels are designed to operate safely at a specific pressure and temperature, technically referred to as the "Design Pressure" and "Design Temperature". A vessel that is inadequately designed to handle a high pressure constitutes a very significant safety hazard. Because of that, the design and Certification of pressure vessels is governed by design codes such as The ASME Boiler and Pressure Vessel Code in North America, the Pressure Equipment Directive of the EU (PED), Japanese Industrial Standard (JIS), CSA B51 in Canada, AS1210 in Australia and other international standards like Lloyd's, Germanischer Lloyd, Det Norske Veritas, Stoomwezen etc. Pressure vessels can theoretically be almost any shape, but shapes made of sections of spheres, cylinders and cones are usually employed. More complicated shapes have historically been much harder to analyse for safe operation and are usually far harder to construct. Theoretically a sphere would be the optimal shape of a pressure vessel.

Unfortunately the sphere shape is difficult to manufacture, therefore more expensive, so most of the pressure vessels are cylindrical shape with 2:1 semi elliptical heads or end caps on each end. Smaller pressure vessels are arranged from a pipe and two covers. Disadvantage of these vessels is the fact that larger diameters make them relatively more expensive. Generally, almost any material with good tensile properties that is chemically stable in the chosen application can be employed. Many pressure vessels are made of steel.

\section{Using Method of (ASME Section II \& VIII, Div1) Calculation}

\subsection{Selection of Materials by using (ASME Section II: A,D)}

The (Section II: A, D) is used to determine selected materials with full description, it permits to use codes for components with different constructions[3].

The main component of any vessel is metal shells with different dimensions on bottom, top and wall. All these dimensions should be suitable with codes under the authority of the designer himself.

ISBN: 978-81-936820-6-7

655

Series: AIJR Proceedings

Proceedings DOI: $10.21467 /$ proceedings.4 


\subsection{Design of Vessels by using (ASME Section VIII, Div1)}

This code (standard) is used for designing vertical tanks (vessels), according to minimum requirements of design without any failure of tank parts. The specialized code for the vessels those used within range of $(0.1 \mathrm{MPa}$ to $20 \mathrm{MPa})$ and for this range most of vertical vessels are selected [9]. The cylindrical pressure vessel composed of: (Shell - Head - Nozzles - Base support).

\subsubsection{Shell Design}

The ASME codes presents basic rules while designing shells. It is clear that the thickness of these shells is main consideration, the welding operation on vessels is necessary too. The used thickness equations are:

- In case of circumference stresses (longitudinal welding)

Where: $\quad(\mathrm{p}<0.385 \mathrm{SE}) \quad \mathrm{t}_{\mathrm{s}}=\frac{\mathrm{PR}}{\mathrm{SE}-0.6 \mathrm{P}} \quad, \quad \mathrm{P}_{\mathrm{s}}=\frac{\mathrm{SE} t_{s}}{\mathrm{R}+0.6 \mathrm{t}_{s}}$

- In case of longitudinal stresses (circumference welding)

Where: $\quad(p<1.25 S E) \quad t_{s}=\frac{P R}{2 S E+0.4 P} \quad, \quad P_{S}=\frac{2 S E t_{s}}{R-0.4 t_{S}}$

Where:

$\mathrm{t}_{\mathrm{s}}=$ Shell thickness.

$\mathrm{P}=$ Designing pressure.

$\mathrm{P}_{\mathrm{s}}=$ Maximum pressure.

$\mathrm{R}=$ Internal Radius.

$\mathrm{S}=$ Maximum allowable stress.

$\mathrm{E}=$ Coefficient of connection of welding.

Note that: $\mathrm{E}=1.0$ if radiated test is used, meanwhile $\mathrm{E}=0.7$ is used if non-radiated tests are used

\subsubsection{Heads Design}

Most of used closing heads are curved to resist pressure, reduce thickness and cost reduction. There are many types of closing heads and mostly used is semi-elliptical head. In this type the base diameter to the high $=\frac{\mathrm{D}}{\mathrm{h}}=\frac{4}{1}$

The head cover will consist of two main parts are shown in Figure 1:

Spherical radius $=(\mathrm{L}=0.9 \mathrm{D})$

Radius of the neck $=(\mathrm{ri}=0.17 \mathrm{D})$

$t_{h}=\frac{P D}{2 S E-0.2 P} \quad, \quad P_{h}=\frac{2 S E t}{D+0.2 t_{h}}$

Where:

$\mathrm{t}_{\mathrm{h}}=$ head thickness.

$\mathrm{P}=$ Designing pressure.

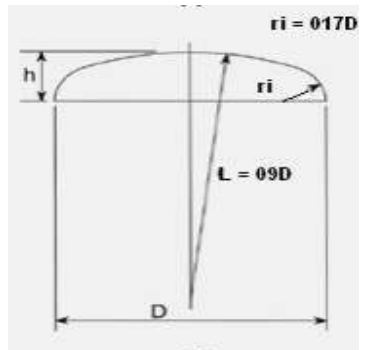

$\mathrm{P}_{\mathrm{h}}=$ Maximum pressure.

Proceedings of First Conference for Engineering Sciences and Technology (CEST-2018), vol. 2 
Design of Vertical Pressure Vessel Using ASME Codes

$\mathrm{S}=$ Maximum allowable stress.

$\mathrm{D}=$ Internal diameter of tank body.

$\mathrm{E}=$ Coefficient of connection of welding.

\subsubsection{Nozzles Design}

During providing the pressure vessels with nozzles, it is important to support these nozzles to avoid or prevent any failure. The type of nozzle is shown in Figure 2

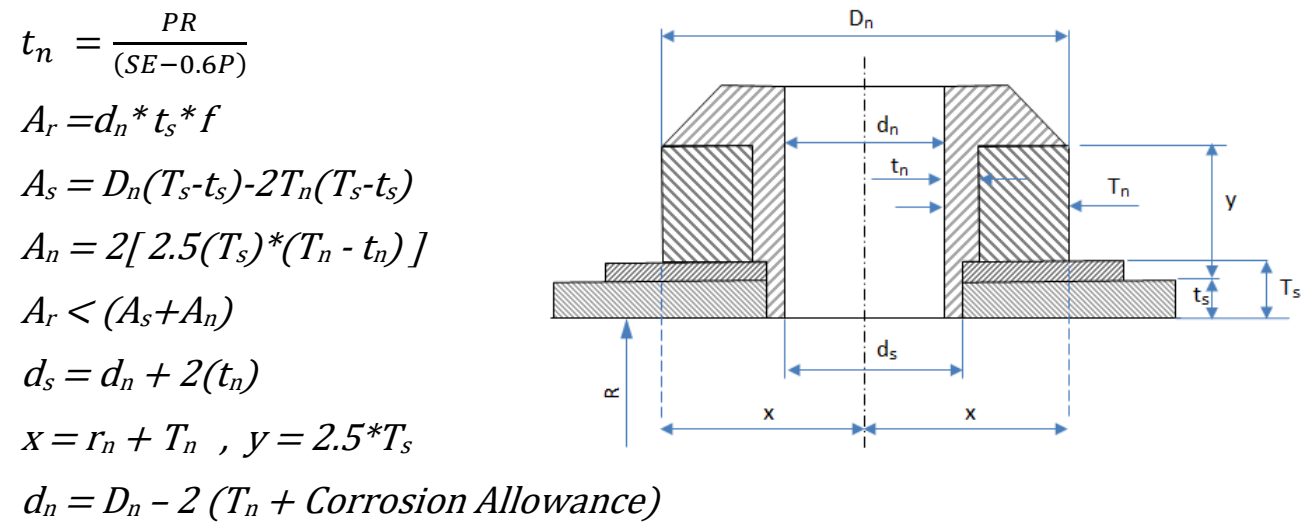

where:

$\mathrm{D}_{\mathrm{n}}=$ External nozzle diameter

$\mathrm{d}_{\mathrm{n}}=$ Internal nozzle diameter

$\mathrm{d}_{\mathrm{s}}=$ Diameter of nozzle on tank wall

$\mathrm{f}=$ correction coefficient $=1$

$\mathrm{t}_{\mathrm{s}}=$ Required thickness of tank

$\mathrm{T}_{\mathrm{s}}=$ Actual body thickness

$\mathrm{t}_{\mathrm{n}}=$ Required nozzle thickness

$\mathrm{T}_{\mathrm{n}}=$ Actual nozzle thickness

$r_{n}=$ Radius of internal hole

$A_{r}=$ Area of nozzle hole

$\mathrm{A}_{\mathrm{s}}=$ Area of connecting region

$A_{n}=$ Area of nozzle wall

\subsubsection{Support Base Design}

During designing of high vessels, the support bases, size, volume, weight, wind and earthquake should be taken into consideration. In this work the legs support were used. The support legs are shown in Figure 3. The number of legs depends on the size of the tank and the size of stored material in the tank. The dimensions of the legs and stresses can be calculated as:

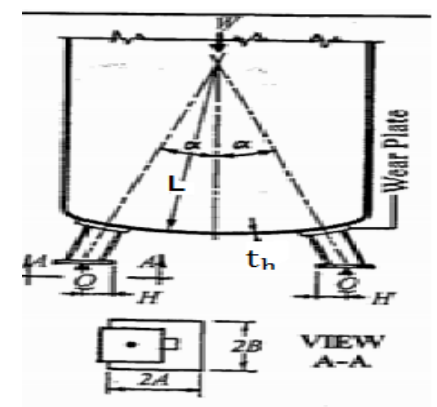

- Longitudinal stresses 


$$
\mathrm{S}_{\mathrm{L}}=\frac{\mathrm{Q}}{\mathrm{t}_{\mathrm{h}}{ }^{2}}\left[\cos \alpha\left(\mathrm{k}_{1}+6 \mathrm{k}_{2}\right)+\frac{\mathrm{H}}{\mathrm{L}} \sqrt{\frac{\mathrm{L}}{\mathrm{t}_{\mathrm{h}}}}\left(\mathrm{K}_{3}+6 \mathrm{~K}_{4}\right)\right]
$$

- Circumference stresses

$$
S_{c}=\frac{Q}{t_{h}^{2}}\left[\cos \alpha\left(k_{5}+6 k_{6}\right)+\frac{H}{L} \sqrt{\frac{L}{t_{h}}}\left(K_{5}+6 K_{6}\right)\right]
$$

Note that the longitudinal Stress always positive values $(\mathrm{k} 2, \mathrm{k} 4, \mathrm{k} 6, \mathrm{k} 8)$ mean while the compressional strain $(\mathrm{k} 1, \mathrm{k} 3, \mathrm{k} 5, \mathrm{k} 7)$ negative values [11].

\subsection{Design Calculations and Results}

The studied vessel with internal pressure not exceeding $(1.55 \mathrm{MPa})$ and internal temperature not exceeding $\left(100^{\circ} \mathrm{C}\right)$. Table 1 shows the initial material used in vessel.

Table 1: Initial material used in vessel

\begin{tabular}{|l|l|}
\hline Part & Material \\
\hline Tank Shell & SA 515- Gr 70 \\
\hline Head Cover & SA 515- Gr 70 \\
\hline Tank Nozzle & SA 106 Gr (B) \\
\hline Support Base & SA 515- Gr 70 \\
\hline Support Legs & SA 106 Gr (B) \\
\hline
\end{tabular}

\subsection{Vessel Shell Calculations}

Table 2: Properties and dimensions of vessel shell

\begin{tabular}{|l|l|}
\hline Internal Pressure & $1.55 \mathrm{MPa}$ \\
\hline Internal Temperature & $100{ }^{\circ} \mathrm{C}$ \\
\hline External Pressure & $0.103 \mathrm{MPa}$ \\
\hline Shell Length (L) & $4000 \mathrm{~mm}$ \\
\hline Internal Tank Diameter (Di) & $1500 \mathrm{~mm}$ \\
\hline Material Type & $\mathrm{SA} 515-\mathrm{Gr} 70$ \\
\hline Permissible Material Stress & $137.9 \mathrm{MPa}$ \\
\hline Link Efficiency & 1.0 \\
\hline Corrosion Permeability & $3 \mathrm{~mm}$ \\
\hline Density of Material & $7.73 \mathrm{~g} / \mathrm{cm}^{3}$ \\
\hline
\end{tabular}

\subsubsection{Vessel Shell Thickness}

Where:

$$
\begin{gathered}
P<0.385 * S * E=1.55<0.385 * 137.9 * 1 \\
t_{s}=\frac{P R}{S E-0.6 P}+\text { c.a }
\end{gathered}
$$


Design of Vertical Pressure Vessel Using ASME Codes

$$
t_{s}=\frac{1.55 *\left(\frac{1500}{2}\right)}{(137.9 * 1)-(0.6 * 1.55)}+3=11.48 \mathrm{~mm}
$$

\subsubsection{Maximum Pressure on Vessel Shell}

$$
\begin{gathered}
p_{s}=\frac{S E t}{R+0.6 t_{s}} \\
p_{s}=\frac{137.9 * 1 * 12}{\left(\frac{1500}{2}\right)+0.6 * 12}=2.19 \mathrm{MPa}
\end{gathered}
$$

\subsubsection{Vessel Shell Mass}

$$
\begin{gathered}
\text { Volume }=\frac{\pi *\left(D_{0}^{2}-D_{i}^{2}\right)}{4} * L \\
\text { Volume }=228004.22 \mathrm{~cm}^{3} \\
\text { Mass }=\text { Volume } * \text { Density } \\
\text { Mass }=228004.22 * 7.73=1762.472 \mathrm{Kg}
\end{gathered}
$$

\subsubsection{Liquid Mass at Vessel Shell}

$$
\begin{gathered}
\text { Volume }=\frac{\pi *\left(D_{i}^{2}\right)}{4} * L \\
\text { Volume }=7068583.47 \mathrm{~cm}^{3} \\
\text { Mass }=\text { Volume } * \text { Density }
\end{gathered}
$$

Liquid Density $=1.00 \mathrm{~g} / \mathrm{cm}^{3}$

$$
\text { Mass }=7068.58 \mathrm{Kg}
$$

\subsection{Head Calculations}

Table 3: Properties and dimensions of head cover

\begin{tabular}{|l|l|}
\hline Head cover type & Semi-Elliptic \\
\hline Internal Tank Diameter & $1500 \mathrm{~mm}$ \\
\hline Material Type & SA $515-$ Gr 70 \\
\hline Permissible Material Stress & $137.9 \mathrm{MPa}$ \\
\hline Link Efficiency & 1.0 \\
\hline Corrosion Permeability & $3 \mathrm{~mm}$ \\
\hline Internal Spherical Radius & $1350 \mathrm{~mm}$ \\
\hline Head High & $375 \mathrm{~mm}$ \\
\hline
\end{tabular}

\subsubsection{Required Head Thickness}

$$
t_{h}=\frac{P D}{2 S E-0.2 P}+c . a
$$




$$
\left(\text { use } t_{h}=12 \mathrm{~mm}\right) \quad t_{h}=11.44 \mathrm{~mm}
$$

\subsubsection{Maximum Pressure at the Head}

$$
\begin{gathered}
P_{h}=\frac{2 S E t}{D+0.2 t_{h}} \\
P_{h}=\frac{2 * 137.9 * 1 * 12}{1500+0.2 * 12}=2.2 \mathrm{MPa}
\end{gathered}
$$

\subsubsection{Mass of Head}

$$
\begin{gathered}
\text { Volume }=\frac{2}{3} * \pi\left(L^{2}-L i^{2}\right) * h \\
\text { Volume }=25559.99 \mathrm{~cm}^{3} \\
\text { Mass }=\text { Volume } * \text { Density } \\
\text { Mass }=25559.99 * 7.73 \\
\text { Mass }=197.58 \mathrm{~kg} \\
\text { Mass of two heads }=197.58 * 2=395.16 \mathrm{~kg}
\end{gathered}
$$

\subsubsection{Liquid Mass at Head}

$$
\begin{gathered}
\text { Volume }=\frac{2}{3} * \pi\left(\mathrm{Li}^{2}\right) * h \\
\text { Volume }=\frac{2}{3} * \pi\left(135^{2}\right) * 37.5=1431388.153 \mathrm{~cm}^{3} \\
\text { Mass }=\text { Volume } * \text { Density }
\end{gathered}
$$

Liquid Density $=1.00 \mathrm{~g} / \mathrm{cm}^{3}$

$$
\text { Mass }=1431.388 \mathrm{Kg}
$$

Liqud Mass of two heads $=2862.776 \mathrm{~kg}$

\subsection{Nozzle Calculations}

Table 4: Properties and dimensions of tank nozzle

\begin{tabular}{|l|l|}
\hline Nozzle Length & $200 \mathrm{~mm}$ \\
\hline External Nozzle Diameter & $203 \mathrm{~mm}$ \\
\hline Material Type & SA 106 Gr (B) \\
\hline Permissible Material Stress & $117.9 \mathrm{MPa}$ \\
\hline Link Efficiency & 1.0 \\
\hline Corrosion Permeability & $3 \mathrm{~mm}$ \\
\hline
\end{tabular}

\subsubsection{Required Nozzle Thickness}

$$
t_{n}=\frac{P R}{(S E-0.6 P)}
$$




$$
\begin{aligned}
t_{n} & =\frac{1.55 *\left(\frac{203}{2}\right)}{(117.9 * 1-0.6 * 1.55)}=1.5 \mathrm{~mm} \\
\text { (use } T_{n} & =10 \mathrm{~mm}, t \mathrm{~s}=12 \mathrm{~mm} \text { and } T s=22 \mathrm{~mm}
\end{aligned}
$$

\subsubsection{Nozzle Reinforcement}

$$
\begin{aligned}
& d_{n}=D_{n}-2\left(T_{n}+\text { Corrosion Allowance }\right) \\
& d_{n}=203-2(10+3), d_{n}=177 \mathrm{~mm} \\
& d_{s}=d_{n}+2\left(t_{n}\right) \\
& d_{s}=177+2(1.5), d_{s}=180 \mathrm{~mm} \\
& A_{r}=d_{n}^{*} t_{s}^{*} f \\
& A_{r}=177^{*} 12^{*} 1, A_{r}=2124 \mathrm{~mm} 2 \\
& A_{s}=D_{n}\left(T_{s}-t_{s}\right)-2 T_{n}\left(T_{s}-t_{s}\right) \\
& A_{s}=203^{*}(22-12)-2^{*} 10^{*}(22-12), A_{s}=1830 \mathrm{~mm} 2 \\
& A_{n}=2\left[2^{*} 1 / 2(T s) \cdot\left(T_{n}-t_{n}\right)\right] \\
& A_{n}=2[2.5(22) \cdot(10-1.5)], A_{n}=935 \mathrm{~mm} 2 \\
& A_{r}<\left(A_{s}+A_{n}\right) \\
& 2124<(1830+935) \\
& x=R_{n}+T_{n} \\
& x=(177 / 2)+10, x=98.5 \mathrm{~mm} \\
& y=2.5^{*} T_{s} \\
& y=2.5^{*} 22, y=55 \mathrm{~mm}
\end{aligned}
$$

\subsubsection{Mass of Nozzle}

$$
\begin{gathered}
\text { Volume }=\frac{\pi *\left(D_{n}^{2}-d_{n}^{2}\right)}{4} * L \\
\text { Volume }=\frac{\pi *\left(20.3^{2}-17.7^{2}\right)}{4} * 20=1551.95 \mathrm{~cm}^{3} \\
\text { Mass }=\text { Volume } * \text { Density } \\
\text { Mass }=11.99 \mathrm{~kg} \\
\text { Mass of two nozzles }=11.99 * 2=23.99 \mathrm{~kg}
\end{gathered}
$$

\subsubsection{Total Mass of Pressure Vessel}

Total mass of vessel parts $=130.9+23.99+395.16+1762.472=2312.5 \mathrm{~kg}$

Total liquid mass $=2862.7763+7068.58=9931.36 \mathrm{~kg}$

Total mass $\left(\mathrm{T}_{\mathrm{m}}\right)=9931.36+2312.5=12243.9 \mathrm{~kg}$ 
Yahya et al., CEST-2018, AIJR Proceedings 4, pp.653-664, 2018

\subsection{Design of Pressure Vessel Support}

Table 5: Properties and dimensions of vessel support

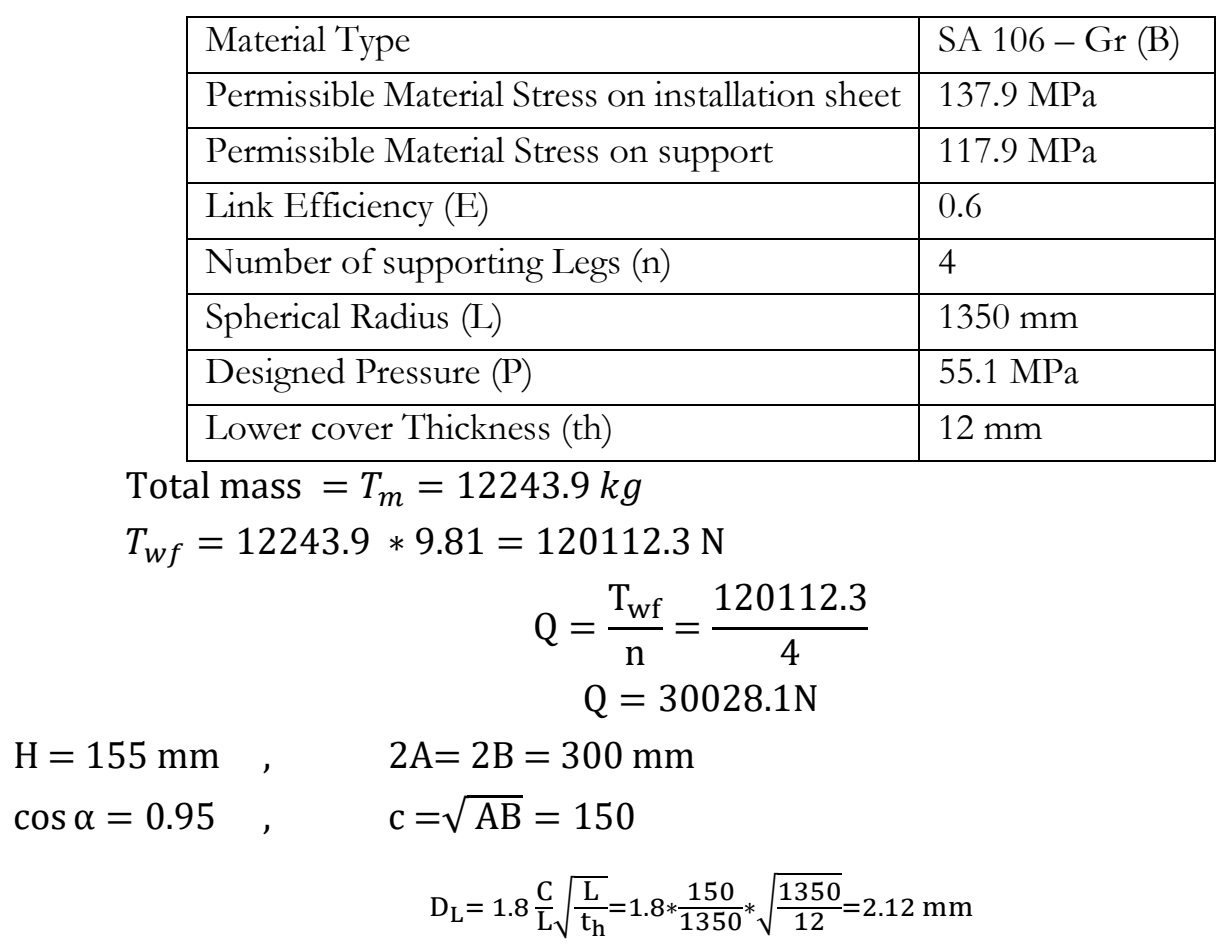

From charts 1,2,3,4 values of $\mathrm{K}_{1}$ to $\mathrm{K}_{8}$ can be defined [11].

$\begin{array}{llll}\mathrm{K}_{1}=0.055 & \mathrm{~K}_{2}=0.02 & \mathrm{~K}_{3}=0.06 & \mathrm{~K}_{4}=0.02 \\ \mathrm{~K}_{5}=0.015 & \mathrm{~K}_{6}=0.01 & \mathrm{~K}_{7}=0.02 & \mathrm{~K}_{8}=0.01\end{array}$

\subsubsection{Calculations of supporting leg dimensions}

$$
\begin{gathered}
Q=30028.1 \mathrm{~N} \\
E * S=\frac{Q}{A}=\frac{Q}{\frac{\pi}{4}\left(D_{o}{ }^{2}-D_{i}{ }^{2}\right)} \\
0.6 * 117.9=\frac{30028.1}{\frac{\pi}{4}\left(D_{o}{ }^{2}-75^{2}\right)} \\
D_{o}=79 \mathrm{~mm}
\end{gathered}
$$

\section{$4 \quad$ Finite Element Analyses}

The FE analysis starts with an axisymmetric analysis of pressure vessel. Solid works software is used for the three dimensional modeling of solid structures. The element is defined by eight nodes having three degrees of freedom at each node i.e. translations in the nodal $x, y$, and $z$ directions. The finite element model consists of hemispherical heads, cylindrical shell and legs support. In boundary condition, the vessel is supported at the end corners and internal pressure of $1.55 \mathrm{MPa}$ is applied at the inner surface. The boundary condition for hemispherical

Proceedings of First Conference for Engineering Sciences and Technology (CEST-2018), vol. 2 662 
Design of Vertical Pressure Vessel Using ASME Codes

and end connection pressure vessels are shown in the figure. All parts of vessel have been drawn after finishing all designing calculations. All the drawings drawn by SolidWorks Program. The vertical pressure vessel assembly are shown in Figure 4.
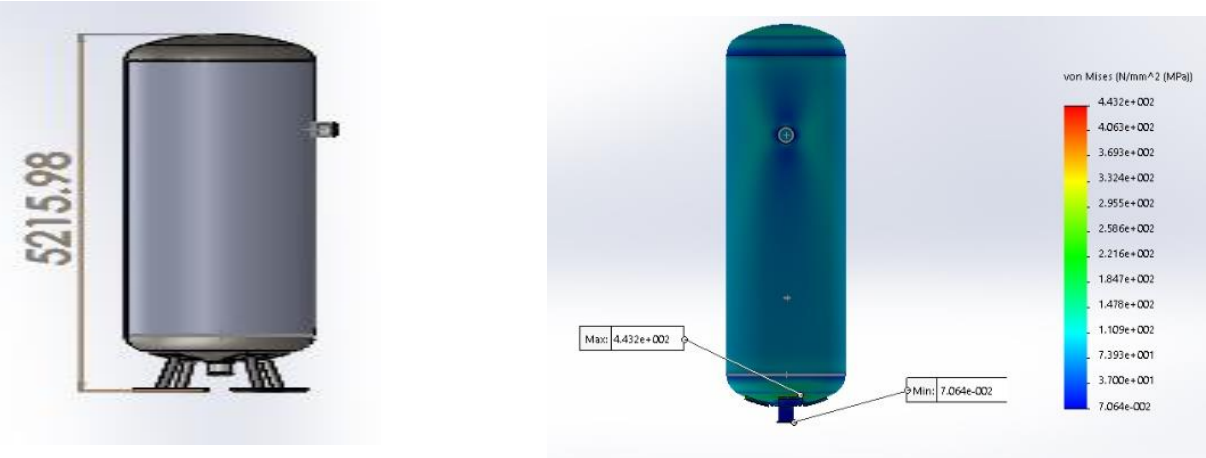

The main purpose of simulation is to determine critical points, stresses concentrations resulted by internal pressure and the distributions of stresses at different regions on vertical pressure vessel with four legs support. The results are shown in Figure 5,6 and 7.
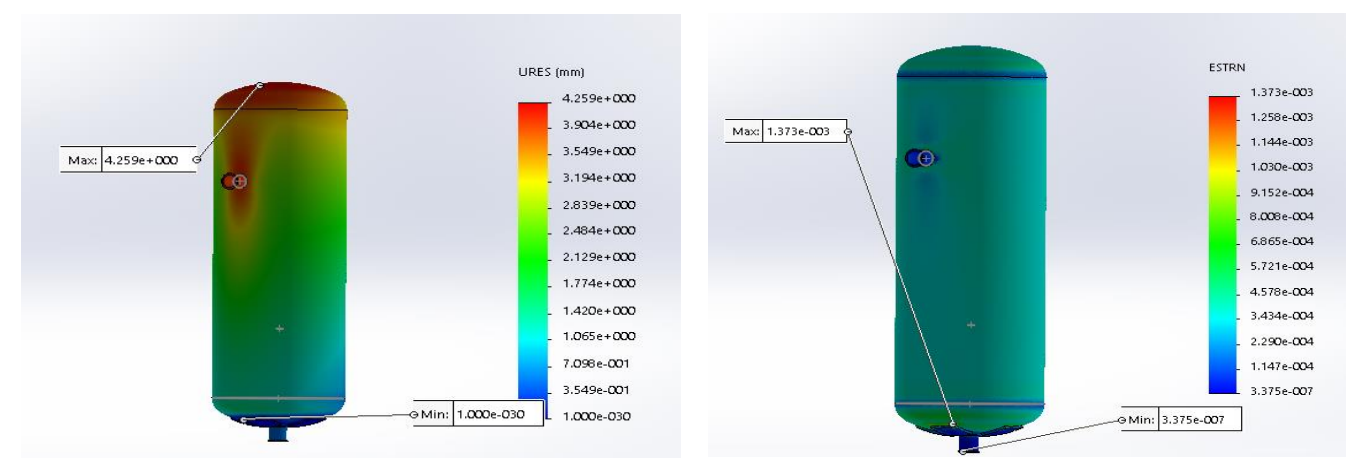

\section{Conclusions}

It is very clear that the pressure vessels are integrated system in terms of parts and competence. Mechanical design of pressure vessel had been done using SolidWorks software. During the designing of Pressure vessels, it is very important to design each part of these vessels individually to obtain more accurate design. All the pressure vessel components are selected on basis of available ASME standards and the manufactures also follow the ASME standards while manufacturing the components. The designing simulation concludes that the stresses concentration regions concentrated on the regions that connect between the bottom of the tank and the fixing base as well as the regions of fixing of the nozzle on the tank body. Also the designing simulation concludes that the most affected regions to displacement by internal 
pressure are the away regions from fixing points (i.e., farther away from installation points the higher displacement value.)

\section{References}

[1] A. Eljondi, "Tanks for Petroleum and Control,” Books, 2015.

[2] M. Hassn and A. Eljondi, "Study of allowances External loads at nozzle/shell junctions of petroleum tanks," Journal of Engineering Sciences, First edition, Damusq 2006.

[3] P. Apurva, "Design and Analysis of Pressure Vessel," International Journal of Innovative Research in Technology \& Science, Mumbai 2011.

[4] B. Thakkar and S. Thakkar, "Design of Pressure Vessel Using ASME Code, SECTION VIII, DIVISION 1," International Journal of Advanced Engineering Research and Studies, India 2012.

[5] V. Kumar, N. Kumar, S. Angra and P. Sharma, "Design of Saddle Support for Horizontal Pressure Vessel," International Journal of Mechanical, Aerospace, Industrial, Mechatronic and Manufacturing Engineering, 2014.

[6] M. Bhatt, A. Gohil, H. Shah and N. Patel. "Design Calculation Of Nozzle Junction Based On ASME Pressure Vessel Design Code," International Journal of Advance Engineering and Research Development, India 2014.

[7] ASME COMPANY. "ASME Boiler and Pressure Vessel Code, VIII Division 1, " New York, 2010.

[8] E. Kaynejad. "Pressure Vessel Design,fabrication and test ASME section VIII, div. 1 ,"

[9] M. DENNIS, "PRESSURE VESSEL DESIGN MANUAL," Third edition, USA, 2004.

[10] V. Patil, "Determination of Safety of Inclined Leg Support for Pressure Vessel Subjected to Arbitrary Wind Load Using FEA," International Journal of Innovations in Engineering and Technology, Vol. 2, 2013

[11] E. Megyesy "Pressure vessel hand book,", Oklahoma 2001. 